\title{
Pengaruh Modal, Tenaga Kerja dan Pengalaman Terhadap Produksi Pengolahan Ubur-Ubur di Desa Temajuk
}

\author{
The effect of capital, labor and experience on jellyfish processing \\ production in temajuk village \\ Rivaldo $^{1}$, Saifullah $^{*}$, Uray Januardy ${ }^{1}$ \\ ${ }^{1}$ Politeknik Negeri Sambas
}

\section{Info Artikel: \\ Diterima : Jan 2021 \\ Disetujui : Mar 2021 \\ Dipublikasi : Mar 2021}

\section{Kata Kunci:}

Modal, Tenaga Kerja, Pengalaman, Pengaruh, Temajuk

Keywords:

Capital, Labor, Experience, Effect, Temajuk

*Korespondensi:

saifullahtatang@yahoo.co.id

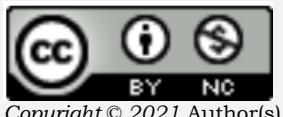

http://ojs.poltesa.ac.id/index.php/nekton

\begin{abstract}
Abstrak. Tujuan penelitian ini adalah untuk mengetahui pengaruh modal, tenaga kerja dan pengalaman terhadap produksi pengolahan ubur-ubur di Desa Temajuk. Metode yang digunakan adalah observasi, wawancara dan kuisioner dengan data primer dan data sekunder. Data yang telah didapatkan di analisis dengan metode hitung uji korelasi menggunakan SPSS versi 25. Hasil pada uji korelasi variabel modal didapat $R$ hitung $0,813>R$ tabel 0,514 , hasil tersebut menunjukan variabel modal berpengaruh terhadap variabel hasil produksi. Untuk variabel tenaga kerja didapat $\mathrm{R}$ hitung 0,793 > R tabel 0,514, hasil tersebut menunjukan variabel tenaga kerja berpengaruh terhadap variabel hasil produksi. Untuk variabel pengalaman didapat $R$ hitung $0,273<R$ tabel 0,514 hasil tersebut menunjukan variabel pengalaman tidak berpengaruh terhadap variabel hasil produksi.
\end{abstract}

\begin{abstract}
The purpose of this study is to know the effect of capital, labor and experience on jellyfish processing production in Temajuk Village. The method used are observation, interviews and questionnaires with primary data and secondary data. The data that has been obtained are analyzed by the correlation test method using SPSS version 25. The results of the correlation test for the capital variable obtained $R_{\text {count }} 0,813>R_{\text {table }} 0,514$, the results show that the variable of capital has an effect on the variable production results. For the labor variable, the $R_{\text {count }}$ is $0,793>R_{\text {table }} 0,514$, this result shows that ther labor variable has an effect on the variable of production results. For the experience variable obtained $R_{\text {count }} 0,273<R_{\text {table }} 0,514$ the results show that the experience variable has no effect on the production yield variable.
\end{abstract}

\section{PENDAHULUAN}

Desa Temajuk mempunyai panjang pantai mencapai $63 \mathrm{~km}$ dari tanjung Dato hingga ke Mutusan dan salah satu pusat pengolahan uburubur terbesar yang ada di Kalimantan Barat. Desa Temajuk juga memiliki hasil lautnya yang melimpah yaitu ubur-ubur salah satu tempat produksi ubur-ubur yang ada di Kalimantan Barat yaitu berada di Desa Temajuk. Ubur-ubur di Desa Temajuk bersifat musiman sehingga pada saat musimnya ubur-ubur hasil tangkapan nelayan sangat melimpah. Uburubur sifatnya tidak tahan lama kalau tidak cepat ditangani ubur-ubur akan cepat busuk dan rusak sehingga tidak bisa diproduksi maka dari itu perlu modal, tenaga kerja dan pengalaman untuk menanganinya dan memperosesnya. Ubur-ubur diproses dengan berbagai tahapan seperti di 
tampung terlebih dahulu di tempat penampungan, pencucian, pemberian tawas, soda dan penggaraman.

Ubur-ubur basah dengan berat berkisar 6-8 $\mathrm{kg}$ akan menghasilkan 0,3 kg ubur- ubur kering. Untuk menghasilkan ubur-ubur kering maka harus diperlukan modal yang besar. Proses pengolahan ubur-ubur para pengusaha biasanya mendapatkan modal dari penampung hasil olahannya sehingga harga jual ubur-ubur sudah ditentukan oleh pemberi modal seperti penampung (agen) dan terikat harus menjual hasil olahannya ke penampung (agen). Olahan ubur-ubur bagi pengusaha yang mempunyai modal bebas untuk memasarkan hasil olahan ubur-uburnya dan harga jualnya juga berbeda untu pemasarannya harus tepat dan lancar biasanya pemasaran olahan ubur-ubur dipasarkan keberbagai tempat yaitu ke Pemangkat, Pontianak, Cina, Korea hingga ke Malaysia. Pengalaman sangatlah penting dalam pengolahan maupun pemasaran ubur-ubur agar ubur-ubur yang diolah mendapat kualitas yang baik. Pengamatan di lapangan pengolahan ubur-ubur diperlukan tenaga kerja yang banyak dengan banyaknya tenaga kerja maka pekerjaan yang dilakukan menjadi efektif dan efisien dengan banyaknya tenaga kerja maka modal yang dikeluarkan besar.

Modal, tenaga kerja dan pengalaman tentunya memberikan suatu pengaruh terhadap produksi usaha pengolahan ubur-ubur. Oleh karena itu, penelitian ini penting dilakukan untuk mengidentifikasi pengaruh modal, tenaga kerja dan pengalaman usaha terhadap produksi pengolahan uburubur serta penelitian ini belum pernah dilakukan sebelumnya. Sehingga penelitian ini dapat memberikan manfaat dan informasi kepada pembaca dan diharapkan dapat menjadi salah satu masukan terhadap usaha produksi pengolahan ubur-ubur di Desa Temajuk.

\section{METODE PENELITIAN}

Penelitian ini dilakukan pada bulan Februari 2020 sampai dengan bulan Juni 2020. Penelitian ini berlokasi di Desa Temajuk, Kecamatan Paloh, Propinsi Kalimantan Barat. Penelitian ini dilakukan di Desa Temajuk dengan pertimbangan bahwa Desa Temajuk memiliki unit usaha pengolahan ubur-ubur, jika dibandingkan dengan daerah lain yang belum memiliki usaha yang sama.

Jenis penelitian yang digunakan dalam penulisan skripsi ini adalah jenis penelitian kuantitatif. Penelitian kuantitatif yaitu penelitian yang keadaannya dapat dinyatakan secara numerik (Suryana, 2010). Metode yang digunakan dalam penelitian ini adalah metode deskriptif yang tertuju pada pemecahan masalah yang ada pada masa sekarang. Penelitian ini dilakukan untuk memberikan gambaran yang lebih detail mengenai suatu gejala atau fenomena. Metode deskriptif yaitu metode yang digunakan untuk 
mencari unsur - unsur, ciri - ciri, sifat - sifat suatu fenomena. Metode ini dimulai dengan mengumpulkan data, menganalisis data dan menginterpresentasikannya (Suryana, 2010).

Populasi dalam penelitian ini adalah seluruh pengolah ubur-ubur yang ada di Desa Temajuk sebanyak 15 orang. Jenis ubur-ubur yang ada di Desa Temajuk adalah jenis ubur-ubur yang berasal dari perairan asin atau laut. Mengingat jumlah populasinya di Desa Temajuk sedikit maka penelitian ini dengan seluruh jumlah populasi yang ada dijadikan sampel. Menurut Sugiyono (2015) sampel jenuh merupakan teknik pengambilan sampel bila semua jumlah anggota populasi dijadikan sampel. Hal ini sering dilakukan jika jumlah sampel populasi relatif kecil kurang dari 30 orang atau sebuah penelitian yang ingin membuat generalisasi dengan kesalahan yang kecil yang menjadi sampel dalam penelitian ini yaitu sebanyak 15 responden. Metode penelitian diambil menggunakan sampel jenuh (sensus) yaitu jumlah seluruh populasi dijadikan sampel dengan cara mendatangi ke tempat pengolahan ubur-ubur. Pada penelitian ini terdapat dua variabel yaitu: variabel bebas (independent variable) dan variabel terikat (dependent variable) :

1. Variabel bebas (independent variable), adalah variabel yang menjadi sebab timbulnya atau berubahnya variabel dependen (variable terikat) Yang menjadi variabel bebas dalam penelitian ini adalah modal, tenaga kerja dan pengalaman.

2. Variabel terikat (dependent variable) merupakan variabel yang dipengaruhi atau yang menjadi akibat, karena adanya variabel bebas. Yang menjadi variabel terikat dalam penelitian ini yaitu produksi pengolahan ubur-ubur.

Terkait teknik analisis data yang digunakan menggunakan uji korelasi, dilakukan untuk mengetahui hubungan atau pengaruh secara signifikan atau tidak dari variabel independen terhadap variabel dependen. Pengujian tersebut menggunakan aplikasi SPSS versi 25 untuk menjawab tujuan yaitu mengetahui pengaruh modal $\left(\mathrm{X}_{1}\right)$, tenaga kerja $\left(\mathrm{X}_{2}\right)$ dan pengalaman usaha $\left(\mathrm{X}_{3}\right)$ terhadap produksi pengolahan ubur-ubur $(\mathrm{Y})$. Hipotesis dari penelitian ini, jika $\mathrm{R}_{\text {hitung }}<\mathrm{R}_{\text {tabel }}$ maka $\mathrm{H}_{0}$ diterima dan $\mathrm{H}_{\mathrm{a}}$ ditolak dan sebaliknya jika $\mathrm{R}_{\text {hitung }}>\mathrm{R}_{\text {tabel }}$ maka $\mathrm{H}_{0}$ ditolak dan $\mathrm{H}_{\mathrm{a}}$ diterima.

\section{HASIL DAN PEMBAHASAN}

\section{Modal Tetap}

Modal tetap yang digunakan dalam produksi pengolahan ubur-ubur sebagai modal yang dikeluarkan untuk pembelian terpal, keranjang, mesin robin, atap, paku, kayu, mesin pemutar kaki ubur-ubur, gerobak, sikat, cool box, gayung, cangkul, sekop, palu, gergaji, golok, tali rapia,bahan baku dan 
yang terakhir penyapu. Modal tetap yang digunakan dalam pengolahan ubur-ubur dapat dilihat pada Tabel 1.

Tabel 1. Modal tetap produksi pengolahan ubur-ubur

\begin{tabular}{ccc}
\hline Interval Modal Tetap (Rp) & Jumlah (Orang) & Persentase (\%) \\
\hline Rp 81.307.000 - Rp 207.151.200 & 7 & $46.67 \%$ \\
Rp 207.151.201 - Rp 332.995.400 & 4 & $26.67 \%$ \\
Rp 332.995.401 - Rp 458.839.600 & 2 & $13.33 \%$ \\
Rp 458.839.601 - Rp 584.683.800 & 0 & $0 \%$ \\
Rp 584.683.801 - Rp 710.528.000 & 2 & $13.33 \%$ \\
\hline Jumlah & 15 & $100 \%$ \\
\hline
\end{tabular}

\section{Modal tidak tetap}

Modal tidak tetap yang digunakan dalam produksi pengolahan uburubur yaitu sebagai modal yang dikeluarkan untuk pembelian tawas, garam, bensin, pena, buku, bayar gaji karyawan dan bayar sewa tanah. Modal tidak tetap yang digunakan dalam pengolahan ubur-ubur dapat dilihat pada Tabel 2.

Tabel 2. Modal tidak tetap produksi pengolahan ubur-ubur

\begin{tabular}{ccc}
\hline Interval Modal Tetap (Rp) & Jumlah (Orang) & Persentase (\%) \\
\hline Rp 5.995.500 - Rp 11.838.683,2 & 11 & $73,33 \%$ \\
Rp 11.838.683,3 - Rp 17.681.866,4 & 1 & $6,67 \%$ \\
Rp 17.681.866,5 - Rp 23.525.049,6 & 2 & $13,33 \%$ \\
Rp 23.525.049,7 - Rp 29.368.232,8 & 0 & $0 \%$ \\
Rp 29.368.232,9 - Rp 35.211.416 & 1 & $6,67 \%$ \\
\hline Jumlah & 15 & $100 \%$ \\
\hline
\end{tabular}

\section{Tenaga kerja}

Jumlah tenaga kerja pada setiap tempat usaha produksi atau pun pengolahan ubur-ubur bervariasi tergantung skala usaha tersebut. Jika skala usahanya besar maka jumlah tenaga kerja yang dimiliki juga besar dan sebaliknya jika skala kecil maka tenaga kerja yang dimiliki juga sedikit. Secara detail dapat dilihat pada Tabel 3.

Tabel 3. Jumlah Tenaga Kerja Produksi

\begin{tabular}{ccc}
\hline $\begin{array}{c}\text { Interval Jumlah Tenaga Kerja } \\
\text { (orang) }\end{array}$ & $\begin{array}{c}\text { Jumlah Responden } \\
\text { (orang) }\end{array}$ & Persentase (\%) \\
\hline $6-9$ & 5 & $33,34 \%$ \\
$10-12$ & 1 & $6,66 \%$ \\
$13-15$ & 4 & $26,67 \%$ \\
$16-18$ & 1 & $6,66 \%$ \\
1921 & 4 & $26,67 \%$ \\
\hline Jumlah & 15 & $100 \%$ \\
\hline
\end{tabular}




\section{Hasil produksi ubur-ubur}

Proses pengolahan ubur-ubur dari tahap pertama sampai penjualan yang terdiri dari pembersihan, penggaraman sampai pengeringan atau penjualan bisa memakan waktu 10 hari hingga sampai ubur-ubur berkualitas yang diinginkan, hasil produksi pengolahan ubur-ubur dapat dilihat pada Tabel 4.

Tabel 4. Hasil produksi pengolahan ubur-ubur

\begin{tabular}{ccc}
\hline Interval Hasil Produksi (Kg) & Jumlah (Orang) & Persentase (\%) \\
\hline $3.750 \mathrm{Kg}-8.000 \mathrm{Kg}$ & 5 & 33,33 \\
$8.001 \mathrm{Kg}-12.250 \mathrm{Kg}$ & 1 & 6,67 \\
$12.251 \mathrm{Kg}-16.500 \mathrm{Kg}$ & 3 & $20 \%$ \\
$16.501 \mathrm{Kg}-20.750 \mathrm{Kg}$ & 3 & $20 \%$ \\
$20.751 \mathrm{Kg}-25.000 \mathrm{Kg}$ & 3 & $20 \%$ \\
\hline $\mathrm{Jumlah}$ & 15 & $100 \%$ \\
\hline
\end{tabular}

\section{Nilai produksi ubur-ubur}

Berdasarkan pada nilai produksi ubur-ubur di Desa Temajuk yaitu jumlah hasil produksi dikali harga jual produksi. Harga jual hasil produksi berbagai variasi harganya berkisar antara Rp 18.000 sampai dengan $\mathrm{Rp}$ $30.000 / \mathrm{kg}$, jumlah nilai produksi pengolahan ubur-ubur dapat dilihat pada Tabel 5.

Tabel 5. Nilai produksi pengolahan ubur-ubur di Desa Temajuk

\begin{tabular}{ccc}
\hline Interval Nilai Produksi & Jumlah (orang) & Persentase (\%) \\
\hline Rp 93.750.000 - Rp 215.000.000 & 5 & $33,34 \%$ \\
Rp 215.000.001 - Rp 336.250.000 & 2 & $13,33 \%$ \\
Rp 336.250.001 - Rp 457.500.000 & 2 & $13,33 \%$ \\
Rp 457.500.001 - Rp 578.750.000 & 3 & $20 \%$ \\
Rp 578.750.001 - Rp 700.000.000 & 3 & $20 \%$ \\
\hline Jumlah & 15 & 100 \\
\hline
\end{tabular}

\section{Hasil uji korelasi}

Pengujian hipotesis dengan menggunakan Kolerasi untuk meguji pengaruh modal, tenaga kerja dan pengalaman terhadap hasil produksi pengolahan uburubur di desa Temajuk. Hasil pengujian dapat dilihat pada Tabel 6.

Tabel 6. Hasil uji korelasi

\begin{tabular}{|l|l|r|r|r|r|}
\hline \multicolumn{7}{|c|}{ Correlations } \\
\hline \multirow{2}{*}{ Modal } & \multicolumn{2}{|c|}{ Modal } & \multicolumn{1}{|c|}{ Tenaga kerja } & Pengalaman & Hasil produksi \\
& Pearson Correlation & 1 & $.701^{* *}$ & 0.485 & $.813^{* *}$ \\
\cline { 2 - 6 } & Sig. (2-tailed) & & 0.004 & 0.067 & 0.000 \\
\cline { 2 - 6 } & N & 15 & 15 & 15 & 15 \\
\hline \multirow{2}{*}{ Tenaga kerja } & Pearson Correlation & $.701^{* *}$ & 1 & 0.209 & $.793^{* *}$ \\
\cline { 2 - 6 } & Sig. (2-tailed) & 0.004 & & 0.455 & 0.000 \\
\hline
\end{tabular}




\begin{tabular}{|c|c|c|c|c|c|}
\hline & $\mathrm{N}$ & 15 & 15 & 15 & 15 \\
\hline \multirow[t]{3}{*}{ Pengalaman } & Pearson Correlation & 0.485 & 0.209 & 1 & 0.273 \\
\hline & Sig. (2-tailed) & 0.067 & 0.455 & & 0.326 \\
\hline & $\mathrm{N}$ & 15 & 15 & 15 & 15 \\
\hline \multirow{3}{*}{$\begin{array}{l}\text { Hasil } \\
\text { produksi }\end{array}$} & Pearson Correlation & $.813^{* *}$ & $.793^{* *}$ & 0.273 & 1 \\
\hline & Sig. (2-tailed) & 0.000 & 0.000 & 0.326 & \\
\hline & $\mathrm{N}$ & 15 & 15 & 15 & 15 \\
\hline
\end{tabular}

**Correlation is significant at the 0.01 level (2-tailed)

Sumber : Data Olahan SPSS Versi 25

Berdasarkan tabel koefisiensi menunjukan: pertama, variabel modal $\left(\mathrm{X}_{1}\right)$ dari nilai pearson correlation $\mathrm{R}_{\text {hitung }} \mathrm{X}_{1}(0.813)>\mathrm{R}_{\text {tabel }}(0.514)$ sehingga dapat disimpulkan bahwa $\mathrm{H}_{0}$ ditolak $\mathrm{H}_{\mathrm{a}}$ diterima. Oleh karena itu, variabel modal $\left(\mathrm{X}_{1}\right)$ ada hubungan atau berpengaruh pada hasil produksi ubur-ubur. Sedangkan dari nilai signifikansi Sig. (2-tailed) dengan taraf signifikansi 5\% bahwa $\mathrm{X}_{1}(0.000)<\mathrm{a}(0.05)$ maka dapat disimpulkan bahwa $\mathrm{H}_{0}$ ditolak $\mathrm{H}_{\mathrm{a}}$ diterima sehingga variabel modal $\left(\mathrm{X}_{1}\right)$ berpengaruh secara signifikan terhadap hasil produksi pengolahan ubur-ubur.

Jumlah modal yang besar akan meningkatkan hasil produksi dimana modal yang tersedia akan mempengaruhi proses produksi, karena diproses produksi memerlukan biaya yang digunakan baik untuk membeli bahan baku, bayar gaji tenaga kerja, biaya penyusutan aktiva benda dan perbaikan tempat produksi. Jika jumlah modal yang tersedia dapat memenuhi kebutuhan dalam produksi pengolahan ubur-ubur maka proses produksi akan lancar dan pada akhirnya akan mempengaruhi hasil produksi.

Pengusaha pengolahan ubur-ubur biasanya mendapatkan modal dari pemberi modal (agen). Hasil olahan ubur-ubur akan dijual kepada yang memberikan modal dan harga susah ditentukan oleh pemberi modal. Olahan ubur-ubur bagi pengusaha yang mempunyai modal bebas untuk memasarkan hasil olahan ubur-uburnya dan harga jualnya juga berbeda untuk pemasarannya harus tepat dan lancar. Biasanya pemasaran olahan ubur-ubur dipasarkan ke Pemangkat, Pontianak, Jakarta, Jepang, Cina, Korea hingga ke Malaysia. Modal sangatlah penting dalam pengolahan uburubur dengan banyaknya modal maka banyak juga membeli bahan baku dan tingkat produksi juga meningkat. Hal ini sejalan dengan penelitian yang telah dilakukan oleh Herawati (2008); Andriani (2017), dimana hasil penelitiannya menunjukan bahwa variabel modal mempunyai pengaruh signifikan serta menunjukkan hubungan yang searah/positif antara modal dan hasil produksi.

Kedua, variabel tenaga kerja $\left(\mathrm{X}_{2}\right)$ dari nilai pearson correlation $\mathrm{R}_{\text {hitung }}$ $\mathrm{X}_{2}(0.793)>\mathrm{R}_{\text {tabel }}(0.514)$ sehingga dapat disimpulkan bahwa $\mathrm{H}_{0}$ ditolak $\mathrm{H}_{\mathrm{a}}$ diterima. Jadi, variabel tenaga kerja $\left(\mathrm{X}_{2}\right)$ terdapat hubungan atau berpengaruh terhadap hasil produksi ubur-ubur. Sedangkan dari nilai signifikan Sig. (2-tailed) dengan taraf signifikansi 5\% bahwa $\mathrm{X}_{2}(0.000)<\mathrm{a}$ (0.05) maka dapat disimpulkan bahwa $\mathrm{H}_{0}$ ditolak $\mathrm{H}_{a}$ diterima sehingga 
variabel tenaga kerja $\left(\mathrm{X}_{2}\right)$ berpengaruh signifikan terhadap hasil produksi ubur-ubur.

Tenaga kerja berpengaruh terhadap hasil produksi pengolahan uburubur karena proses produksi memerlukan tenaga kerja yang cukup untuk mengolah ubur-ubur jika tidak ada tenaga kerja maka proses produksi pengolahan ubur-ubur tidak akan beroperasi dengan baik dan bisa mengakibatkan gagal produksi. Ubur-ubur di Desa Temajuk bersifat musiman sehingga pada saat musimnya ubur-ubur hasil tangkapan nelayan sangat melimpah. Kemampuan 1 orang tenaga kerja dalam satu kali produksi bisa menghasilkan 535 sampai $1.190 \mathrm{~kg}$. Ubur-ubur sifatnya tidak tahan lama kalau tidak cepat ditangani ubur-ubur akan cepat busuk dan rusak sehingga tidak bisa diproduksi maka dari itu perlu adanya tenaga kerja yang cukup.

Banyak sedikitnya jumlah tenaga kerja dalam produksi pengolahan uburubur itu tergantung besar atau kecilnya modal yang dimiliki. Jika banyak memiliki tenaga kerja maka cepat pekerjaan selesai begitu sebaliknya sedikit tenaga kerja maka lambatlah proses pekerjaan sehingga berpengaruh terhadap hasil produksi. Hasil penelitian ini tidak ada hasil penelitian yang sesuai dengan hasil penelitian sebelumnya yaitu menggunakan pengaruh tenaga kerja terhadap hasil produksi pengolahan ubur-ubur.

Ketiga, variabel pengalaman $\left(\mathrm{X}_{3}\right)$ dari nilai pearson correlation $\mathrm{R}_{\text {hitung }}$ $\mathrm{X}_{2}(0.273)<\mathrm{R}_{\text {tabel }}(0.514)$ sehingga dapat disimpulkan bahwa $\mathrm{H}_{0}$ diterima $\mathrm{H}_{\mathrm{a}}$ ditolak. Jadi, variabel pengalaman $\left(\mathrm{X}_{3}\right)$ tidak ada hubungan atau tidak berpengaruh terhadap hasil produksi ubur-ubur. Sedangkan dari nilai signifikan Sig. (2-tailed) dengan taraf signifikansi 5\% bahwa $\mathrm{X}_{3}(0.326)>\mathrm{a}$ (0.05) maka dapat disimpulkan bahwa $\mathrm{H}_{0}$ diterima $\mathrm{H}_{\mathrm{a}}$ ditolak sehingga variabel tenaga kerja $\left(\mathrm{X}_{3}\right)$ tidak berpengaruh signifikan terhadap hasil produksi ubur-ubur.

Variabel pengalaman tidak berpengaruh terhadap produksi pengolahan ubur-ubur karena pada proses produksi cukup mudah untuk dilakukan. Produksi pengolahan ubur-ubur juga sangat mudah seperti melalui proses penampungan, pembersihan, penggaraman hingga sampai pengeringan dan penjualan proses tersebut memakan waktu samapai 10 hari. Hasil penelitian ini tidak ada hasil penelitian yang sesuai dengan hasil penelitian sebelumnya yaitu menggunakan pengaruh pengalaman terhadap hasil produksi pengolahan ubur-ubur.

\section{Produksi ubur-ubur}

Produksi pengolahan ubur-ubur di Desa Temajuk bahan baku yang didapatkan yaitu langsung dibeli dari nelayan. Ubur-ubur biasa dibeli dengan rata-rata harga $\mathrm{Rp} 2.000$ - Rp 2.500/ekor dan harga jual setelah di olah menjadi Rp 18.000- Rp 28.000/Kg. Proses pengolahan ubur-ubur 
pertama dilakukan penampungan terlebih dahulu kemudian di beri tawas hingga dibiarkan sampai 12 jam, setelah dibiarkan 12 jam tahap selanjutnya proses pembersihan dan langsung penggaraman, proses penggaraman melalui 4 tahapan penggaraman dengan berselang 2 hari setelah melalui proses 4 tahapan penggaraman ubur-ubur langsung tahap pengepengan, pengepengan ada dua persi ada yang 12 jam dan ada yang 24 jam. Tujuan melakukan pengepengan untuk membuang kadar airnya yang terdapat pada olahan ubur-ubur setelah melakukan pengeringan langsung proses penimbangan dan di-packing ke dalam ember dalam 1 ember ditetapkan hanya $18 \mathrm{~kg}$ setelah ini langsung dijual. Pemasaran ubur-ubur biasanya langsung dijual ke Pemangkat, Pontianak, Jakarta, Korea, Jepang, Cina dan Malaysia.

Menjalankan usaha produksi pengolahan ubur-ubur di Desa Temajuk sifatnya musiman dan tidak bisa dijadikan pekerjaan utama hanya menjadi pekerjaan sampingan proses pengolahan ubur-ubur hanya dilakukan pada musim tertentu saja dan pada saat musim ubur-ubur, kadang-kadang 1 tahun sekali hingga 4 tahun sekali sehingga produksi pengolahan uburubur terjeda dan akan berpengaruh pula pada pendapatan pengusaha maupun para nelayan.

\section{KESIMPULAN}

Berdasarkan uji kerolasi bahwa variabel modal dan tenaga kerja memiliki korelasi atau berpengaruh signifikan terhadap proses produksi. Sedangakn variabel pengalaman tidak memiliki korelasi atau tidak berpengaruh signifikan terhadap proses produksi.

\section{DAFTAR PUSTAKA}

Sugiyono. (2015). Metode Penelitian Pendidikan (Pendekatan Kuantitatif,. Kualitatif dan R\&D). Penerbit CV. Alfabeta: Bandung.

Suryana. (2010). Metedologi Penelitian (Model Praktis Penelitian Kuantitatif dan Kualitatif). Universitas Pendidikan Indonesia. Bandung.

Andriani, N.D. (2017). Pengaruh Modal, Tenaga Kerja Dan Bahan Baku

Terhadap Hasil Produksi (Studi Kasus Pabrik Sepatu Pt. Kharisma Baru Indonesia). Equilibrium, 5(2), 151-162. http://doi.org/10.25273/equilibrium.v5i2.1543

Herawati, E. (2008). Analisis Pengaruh Faktor Produksi Modal, Bahan Baku, Tenaga Kerja dan Mesin Terhadap Produksi Glycerine Pada PT. Flora Sawita Chemiondo Medan. [Tesis]. Program Pasca Sarjana Universitas Sumatera Utara. Medan. 